\title{
Update on the Epidemiology of Macrolide-Resistant Mycoplasma pneumoniae in Europe: A Systematic Review
}

\author{
Daniela Loconsole ${ }^{1}{ }^{\mathbb{C}}$, Anna Lisa De Robertis ${ }^{1}$, Anna Sallustio ${ }^{2}$, Francesca Centrone ${ }^{1} \mathbb{C}$, Caterina Morcavallo ${ }^{1} \mathbb{D}$, \\ Silvia Campanella ${ }^{1}$, Marisa Accogli ${ }^{1}$ and Maria Chironna ${ }^{1, *(1)}$
}

1 Department of Biomedical Sciences and Human Oncology-Hygiene Section, University of Bari, 70124 Bari, Italy; daniela.loconsole@uniba.it (D.L.); derobertis.annalisa@gmail.com (A.L.D.R.); francesca.centrone.fc@gmail.com (F.C.); caterinamorcavallo@gmail.com (C.M.); campanella.silvia@libero.it (S.C.); accoisa@gmail.com (M.A.)

2 Hygiene Unit, Azienda Ospedaliero-Universitaria Consorziale Policlinico di Bari, 70124 Bari, Italy; annasallustio@libero.it

* Correspondence: maria.chironna@uniba.it; Tel.: +39-080-5478498; Fax: +39-080-5593887

\section{check for} updates

Citation: Loconsole, D.; De Robertis, A.L.; Sallustio, A.; Centrone, F.; Morcavallo, C.; Campanella, S.; Accogli, M.; Chironna, M. Update on the Epidemiology of

Macrolide-Resistant Mycoplasma pneumoniae in Europe: A Systematic Review. Infect. Dis. Rep. 2021, 13, 811-820. https://doi.org/10.3390/ idr13030073

Academic Editor: Nicola Petrosillo

Received: 24 July 2021

Accepted: 30 August 2021

Published: 2 September 2021

Publisher's Note: MDPI stays neutral with regard to jurisdictional claims in published maps and institutional affiliations.

Copyright: (c) 2021 by the authors. Licensee MDPI, Basel, Switzerland. This article is an open access article distributed under the terms and conditions of the Creative Commons Attribution (CC BY) license (https:/ / creativecommons.org/licenses/by/ $4.0 /)$.

\begin{abstract}
Macrolide-resistant Mycoplasma pneumoniae (MR-MP) infections cause upper and lower respiratory tract infections in both children and adults, and are characterized by a longer duration of symptoms. Here, we undertook a systematic review of studies on MR-MP in Europe. The review meets PRISMA guidelines. The PubMed, Scopus, and Science Direct databases were searched using suitable keywords to identify relevant studies published from 2010 to 2021; 21 studies were included. Overall, a low level of MR-MP spread was reported in Europe. MR-MP spread increased during epidemic waves registered in Europe, particularly in Italy and Scotland, where the highest MR-MP infection rates were registered during the 2010-2011 epidemic. By contrast, no MR-MP infections were reported in Finland and the Netherlands. Continued monitoring of MR-MP in Europe is needed to maintain the low rates of infection. Moreover, a coordinated and structured pan-European surveillance program adequate for public health surveillance is advisable, with the purpose of containing the spread of antimicrobial resistance.
\end{abstract}

Keywords: epidemiology; macrolide-resistant Mycoplasma pneumoniae; Europe; antimicrobial resistance; systematic review

\section{Introduction}

Mycoplasma pneumoniae (MP) is a common cause of upper and lower respiratory tract disease in both children and adults. In the post-pneumococcal conjugate vaccine (PCV) 13 era, MP has become the leading cause of pediatric community-acquired pneumonia (CAP) in countries where PCV13 is included in the national immunization program [1,2]. Clinical symptoms are usually mild, although occasionally MP infection can be life-threatening as it can cause extra-respiratory manifestations, mainly skin lesions, hematologic disorders, and cardiovascular and nervous disease [3-5]. The pathogenesis of such extrapulmonary manifestations is more likely due to the host immune response rather than to the pathogen itself [6]. MP infections are both endemic and epidemic worldwide. Epidemics occur at intervals of 4-7 years [7-9]. It is hypothesized that these fluctuations are related to antigenic shifts in strains, decreased herd immunity in populations, or both $[7,10]$. During such periods, MP is responsible for $25 \%$ of all CAP cases [8], while the incidence drops to $1-8 \%$ between epidemics [11].

The majority of MP infections are self-limiting, especially in adults. Beta-lactam antimicrobial drugs are ineffective against MP since the pathogen lacks a cell wall. Macrolides, tetracyclines, and fluoroquinolones are the first-choice treatments, but only macrolides are recommended for children due to the age-related adverse effects of tetracyclines and fluoroquinolones $[4,12]$. However, the use of tosufloxacin has been approved in Japan for 
pediatric patients since 2010, and recent data showed that no changes in MP susceptibility to this antibiotic have been reported [13]. Inappropriate use, or overuse, of macrolides has led to worldwide reporting of macrolide-resistant MP strains (MR-MP). MR-MP were first isolated from pediatric patients with CAP in 2001 [14]. Since then, the number of resistant strains has increased rapidly year by year [15]. Macrolide resistance phenotypes of MP, which are defined by single nucleotide polymorphisms in the $\mathrm{V}$ domain of the single-copy $23 \mathrm{~S}$ rRNA gene [15,16], are more common in children than in adults [17]. The mutations that induce a high-level of macrolide resistance include the transition A2063G and the transversion A2064G, whereas the A2617G transition confers low-level resistance [15]. Although macrolide resistance is mainly due to point mutations in domain $\mathrm{V}$ of the $23 \mathrm{~S}$ rRNA gene, recent studies show that the macrolide efflux pump may contribute to macrolide resistance [18]. The clinical manifestations of MP infection are similar, regardless of macrolide resistance [19]. However, MR-MP infections lead to a longer duration of fever, cough, hospital stay, and antibiotic administration [20]. MP infection can lead to prolonged carriage; therefore, infected people represent a reservoir for spread to other people [21]. In addition, asymptomatic carriage of MR-MP has been described [22]. Macrolide resistance rates range from $0.2 \%$ in Sweden [23] to $>90 \%$ in China [24]. The present review was conducted to examine the spread of MR-MP in Europe from 2010 to the present day to gain insight into the emergence of resistant strains in European countries in light of the lack of specific surveillance systems.

\section{Materials and Methods}

A systematic review of all peer-reviewed studies concerning MR-MP infections in Europe from 2010 to the present day was performed according to the Preferred Reporting Items for Systematic Reviews and Meta-Analyses (PRISMA) guidelines. First, the PubMed, Scopus, and Science Direct databases were searched to identify relevant literature. Data extraction was performed from January 2010 to June 2021 using the following keywords: “(Mycoplasma pneumoniae) AND (macrolide) AND (resistance) AND (Europe)". The screening of resources took place during the first phase by reading the title and abstract of the studies, followed by removal of duplicates. During the second stage, articles were considered eligible if they met the following inclusion criteria: English language studies, case reports or research articles, and a focus on MP infection. Book chapters, reviews, conference abstracts, practice guidelines, non-European studies, and studies of other pathogens were excluded.

\section{Results}

The initial search identified 1183 articles (Figure 1).

After removing duplicates and studies marked as ineligible by automation tools, 747 articles were screened by title and abstract. Irrelevant articles were excluded, and 20 articles were retrieved for full-text assessment. Of these, only one was suitable. Articles that focused on antibiotic treatments, studies conducted in countries other than in Europe or on pathogens other than MP, and reviews were excluded. Finally, 22 studies were included in the systematic review (Table 1).

In Germany, Dumke et al. reported that the prevalence of MR-MP infections among children and adults during the years 2009-2012 was 3.6\%. The study population included both outpatients and inpatients [25]. Moreover, a prospective study performed on 783 CAP adult patients in the 2011-2012 period showed a 3.1\% MR-MP infection rate among $96 \mathrm{MP}$ positive patients [26]. The reported prevalence of MR-MP remained stable (at 3.0\%) from 2016 to 2018 [27]. A pediatric case of macrolide resistance after macrolide treatment was reported in December 2013 [28]. A pharyngeal swab collected from a 15-year-old patient taken on the first day of hospitalization was positive for a macrolide-susceptible MP strain. On Day 19 from symptom onset, the patient required a new hospital admission due to multiple severe skin lesions. The pharyngeal swab collected during the second hospitalization harbored both wild-type MP sequences and clones carrying two mutations 
typical of a macrolide-resistant strain, suggesting that the MR-MP mutants were selected from the wild-type MP strain [28].

\section{Identification of studies via databases and registers}
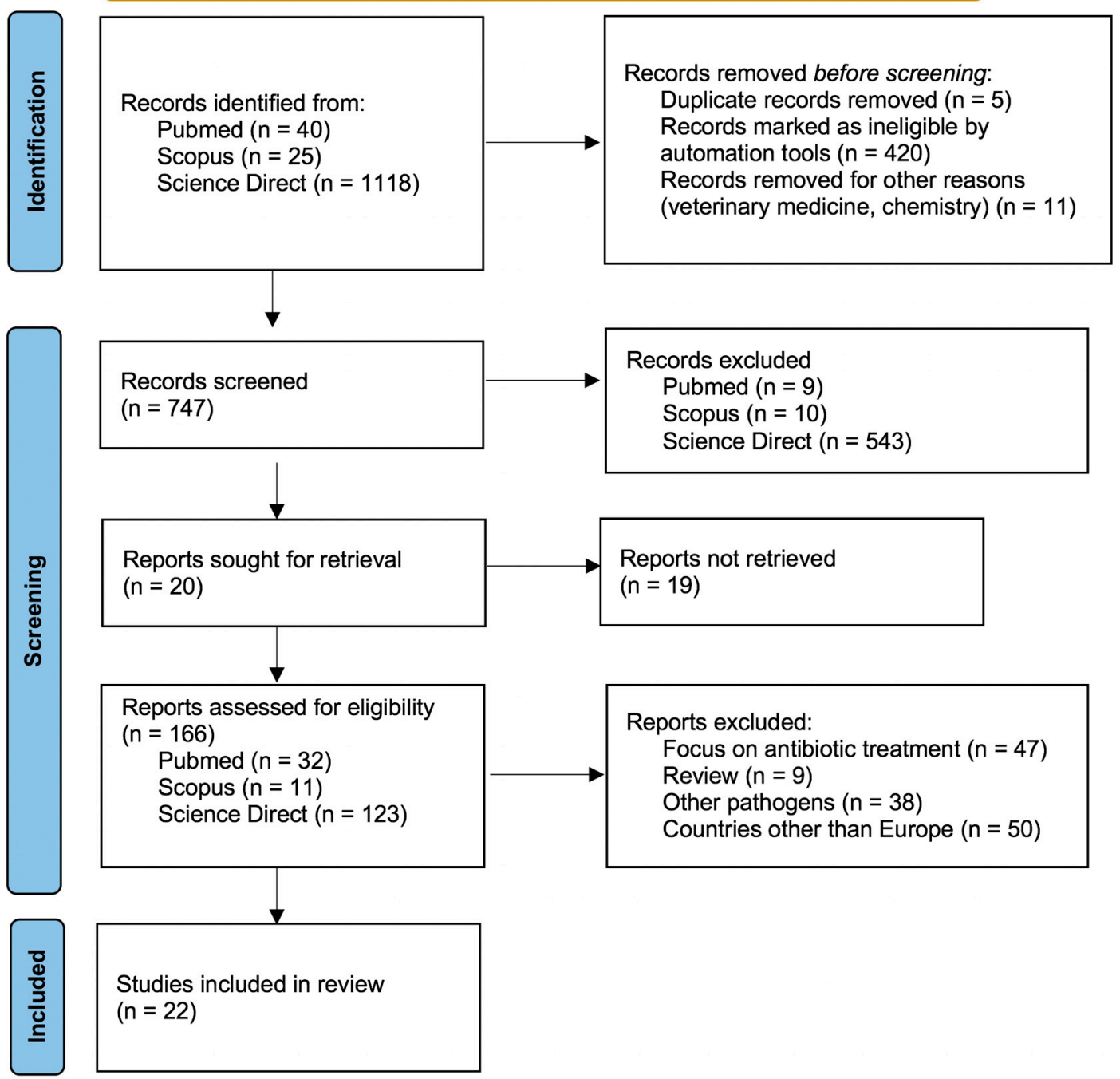

\section{Records screened} $(n=747)$

Records excluded

Pubmed $(n=9)$

Scopus $(n=10)$

Science Direct $(n=543)$
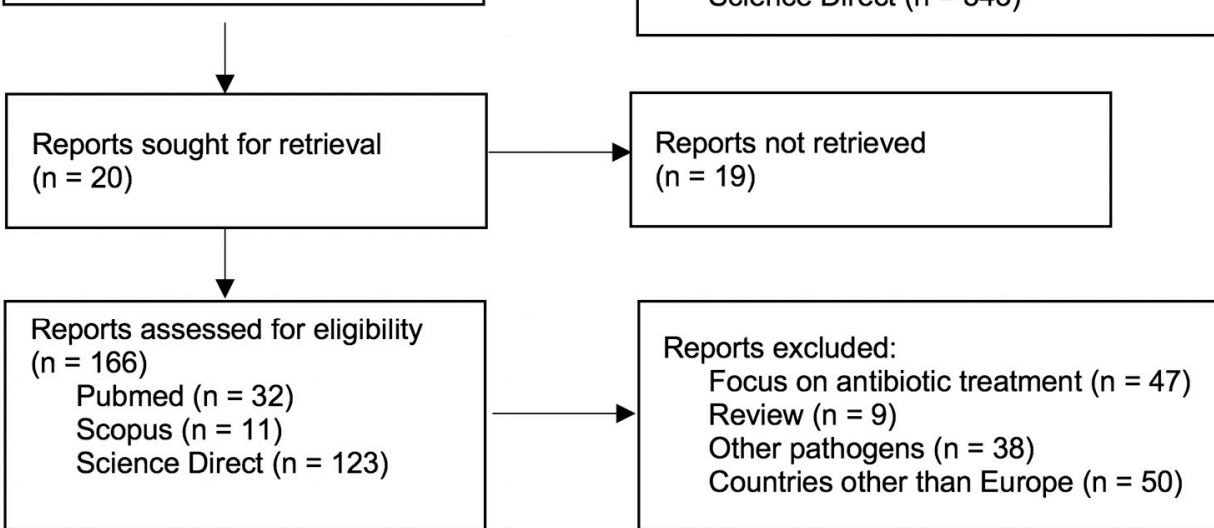

Studies included in review

$(n=22)$

Figure 1. PRISMA flow chart.

Table 1. Studies of the macrolide-resistant Mycoplasma pneumoniae (MR-MP) in Europe (2010-2021).

\begin{tabular}{|c|c|c|c|c|c|c|c|c|}
\hline $\mathrm{N}$. & Authors & Year of Study & Journal & Country & Type of Study & $\begin{array}{c}\text { Population } \\
\text { (Number of MP } \\
\text { Positive Samples) }\end{array}$ & $\begin{array}{c}\text { Diagnostic Methods } \\
\text { for MP } \\
\text { Identification }\end{array}$ & Main Findings \\
\hline 1 & Dumke et al. [25] & 2013 & $\begin{array}{l}\text { Antimicrobial } \\
\text { Agents and } \\
\text { Chemotherapy }\end{array}$ & Germany & $\begin{array}{l}\text { Prospective study of } \\
\text { out- and inpatients }\end{array}$ & $\begin{array}{l}\text { Children and adults } \\
\qquad(\mathrm{n}=84)\end{array}$ & Real-time PCR & $\begin{array}{l}\text { Prevalence of MR-MP was } 3.6 \% \\
\text { during an epidemic period }\end{array}$ \\
\hline 2 & Dumke et al. [26] & 2015 & $\begin{array}{l}\text { Emerging Infectious } \\
\text { Diseases }\end{array}$ & Germany & Prospective study & $\begin{array}{l}\text { Adults } \\
(\mathrm{n}=96)\end{array}$ & Real-time PCR & $\begin{array}{l}\text { Low levels of macrolide } \\
\text { resistance }(3.1 \%) \text { during } \\
2011-2012 \text { period }\end{array}$ \\
\hline 3 & Dumke et al. [27] & 2019 & $\begin{array}{l}\text { Antimicrobial } \\
\text { Agents and } \\
\text { Chemotherapy }\end{array}$ & Germany & Retrospective study & $\begin{array}{l}\text { Children and adults } \\
\qquad(\mathrm{n}=166)\end{array}$ & Real-time PCR & $\begin{array}{l}\text { Low rate of MR-MP infection ( } 3 \% \text { ) } \\
\text { during the 2016-2018 period }\end{array}$ \\
\hline 4 & Dumke et al. [28] & & $\begin{array}{l}\text { International Journal } \\
\text { of Infectious } \\
\text { Diseases }\end{array}$ & Germany & Case report & 15 -year-old boy & Real-time PCR & $\begin{array}{l}\text { Development of macrolide } \\
\text { resistance after macrolide } \\
\text { treatment. Presence of a mixture } \\
\text { of wild-type and } \\
\text { macrolide-resistant strains }\end{array}$ \\
\hline 5 & Chironna et al. [16] & 2011 & $\begin{array}{c}\text { Journal of } \\
\text { Antimicrobial } \\
\text { Chemotherapy }\end{array}$ & Italy & $\begin{array}{l}\text { Prospective study of } \\
\text { hospitalized patients }\end{array}$ & $\begin{array}{l}\text { Children } \\
(\mathrm{n}=43)\end{array}$ & Real-time PCR & $\begin{array}{l}\text { MR-MP prevalence of } 26 \% \text { in } \\
\text { children hospitalized for LRTI }\end{array}$ \\
\hline 6 & Cardinale et al. [19] & 2013 & $\begin{array}{l}\text { Journal of Clinical } \\
\text { Microbiology }\end{array}$ & Italy & $\begin{array}{l}\text { Prospective study of } \\
\text { hospitalized patients }\end{array}$ & $\begin{array}{l}\text { Children } \\
(\mathrm{n}=46)\end{array}$ & Real-time PCR & $\begin{array}{l}\text { The presence of MR-MP does not } \\
\text { change the clinical presentation of } \\
\text { CAP; however, children with } \\
\text { MR-MP infection were more } \\
\text { likely to show longer duration of } \\
\text { fever, cough, and hospitalization }\end{array}$ \\
\hline
\end{tabular}


Table 1. Cont.

\begin{tabular}{|c|c|c|c|c|c|c|c|c|}
\hline N. & Authors & Year of Study & Journal & Country & Type of Study & $\begin{array}{c}\text { Population } \\
\text { (Number of MP } \\
\text { Positive Samples) }\end{array}$ & $\begin{array}{l}\text { Diagnostic Methods } \\
\text { for MP } \\
\text { Identification }\end{array}$ & Main Findings \\
\hline 7 & Chironna et al. [22] & 2016 & Medicine & Italy & $\begin{array}{c}\text { Outbreak } \\
\text { investigation }\end{array}$ & $\begin{array}{l}\text { Children and adults } \\
\qquad(\mathrm{n}=8)\end{array}$ & Real-time PCR & $\begin{array}{l}\text { High transmission rates of } \\
\text { MR-MP infection/carriage within } \\
\text { a single family }\end{array}$ \\
\hline 8 & Loconsole et al. [29] & 2019 & $\begin{array}{l}\text { BioMed Research } \\
\text { International }\end{array}$ & Italy & Retrospective study & $\begin{array}{l}\text { Adults } \\
(\mathrm{n}=15)\end{array}$ & Real-time PCR & $\begin{array}{l}1.3 \% \text { of adults with CAP had a } \\
\text { MR-MP infection }\end{array}$ \\
\hline 9 & Pereyre et al. [30] & 2012 & PLOS One & France & Retrospective study & $\begin{array}{l}\text { Children and adults } \\
\qquad(\mathrm{n}=34)\end{array}$ & Real-time PCR & $\begin{array}{l}\text { MR-MP prevalence of } 3.4 \% \text { in the } \\
2007-2010 \text { endemic period }\end{array}$ \\
\hline 10 & Pereyre et al. [31] & 2013 & $\begin{array}{l}\text { Clinical } \\
\text { Microbiology and } \\
\text { Infection }\end{array}$ & France & $\begin{array}{l}\text { Retrospective study } \\
\text { in hospitalized } \\
\text { patients }\end{array}$ & $\begin{array}{l}\text { Children and adults } \\
\qquad(\mathrm{n}=94)\end{array}$ & $\begin{array}{l}\text { Real-time PCR, } \\
\text { culture, serology }\end{array}$ & $\begin{array}{l}\text { MR-MP prevalence of } 8.3 \% \text { in the } \\
2011 \text { epidemic period }\end{array}$ \\
\hline 11 & Caballero et al. [32] & 2014 & $\begin{array}{l}\text { Antimicrobial } \\
\text { Agents and } \\
\text { Chemotherapy }\end{array}$ & Spain & Case report & 23-year-old female & $\begin{array}{l}\text { Real-time PCR, } \\
\text { culture, serology }\end{array}$ & $\begin{array}{c}\text { First description of MR-MP in a } \\
\text { Chinese 23-year-old female } \\
\text { coming back from China } 13 \text { days } \\
\text { before CAP onset }\end{array}$ \\
\hline 12 & Rivaya et al. [33] & 2020 & $\begin{array}{c}\text { Journal of } \\
\text { Antimicrobial } \\
\text { Chemotherapy }\end{array}$ & Spain & Retrospective study & $\begin{array}{l}\text { Children and adults } \\
\qquad(\mathrm{n}=138)\end{array}$ & $\begin{array}{l}\text { Real-time PCR, } \\
\text { serology }\end{array}$ & $\begin{array}{l}\text { MR-MP detected in } 8 \% \text { of } \\
\text { infections in the 2013-2017 period }\end{array}$ \\
\hline 13 & Ferguson et al. [34] & 2013 & $\begin{array}{l}\text { Journal of Medical } \\
\text { Microbiology }\end{array}$ & Scotland & Retrospective study & $\begin{array}{l}\text { Children and adults } \\
\qquad(\mathrm{n}=32)\end{array}$ & Real-time PCR & $\begin{array}{l}\text { MR-MP prevalence of } 19 \% \text { in the } \\
2010-2011 \text { period, which was } \\
\text { associated with a significant } \\
\text { burden on local hospital } \\
\text { admissions }\end{array}$ \\
\hline 14 & Brown et al. [35] & 2015 & Euro Surveillance & England and Wales & Retrospective study & $\begin{array}{l}\text { Children and adults } \\
\qquad(\mathrm{n}=43)\end{array}$ & qPCR & $\begin{array}{l}\text { MR-MP detected in } 9.3 \% \text { of } \\
\text { collected samples }\end{array}$ \\
\hline 15 & Kogoy et al. [36] & 2015 & Euro Surveillance & Slovenia & $\begin{array}{l}\text { Retrospective study } \\
\text { in out- and } \\
\text { inpatients }\end{array}$ & $\begin{array}{l}\text { Children and adults } \\
\qquad(\mathrm{n}=1255)\end{array}$ & $\begin{array}{l}\text { Real-time PCR, } \\
\text { culture }\end{array}$ & $\begin{array}{l}\text { Sporadic identification by } \\
\text { MR-MP in the 2006-2014 period } \\
\text { covering two nationwide } \\
\text { epidemics }\end{array}$ \\
\hline 16 & Kogoy et al. [37] & 2018 & $\begin{array}{c}\text { European Journal of } \\
\text { Clinical } \\
\text { Microbiology \& } \\
\text { Infectious Disease }\end{array}$ & Slovenia & $\begin{array}{l}\text { Retrospective study } \\
\text { in out- and } \\
\text { inpatients }\end{array}$ & $\begin{array}{l}\text { Children and adults } \\
\quad(\mathrm{n}=1477)\end{array}$ & $\mathrm{qPCR}$, culture & $\begin{array}{l}0.8 \% \text { of MP isolated in the } \\
2006-2016 \text { period showed } \\
\text { macrolide resistance }\end{array}$ \\
\hline 17 & Nilsson et al. [38] & 2014 & $\begin{array}{c}\text { Scandinavian } \\
\text { Journal of Infectious } \\
\text { Diseases }\end{array}$ & Sweden & Prospective study & $\begin{array}{l}\text { Children and adults } \\
\qquad(\mathrm{n}=38)\end{array}$ & Real-time PCR & $\begin{array}{c}1 / 38 \text { cases developed MR } \\
\text { mutations during macrolide } \\
\text { treatment }\end{array}$ \\
\hline 18 & Gullsby et al. [23] & 2019 & $\begin{array}{l}\text { Journal of Clinical } \\
\text { Microbiology }\end{array}$ & Sweden & Retrospective study & $\begin{array}{l}\text { Children and adults } \\
\qquad(\mathrm{n}=578)\end{array}$ & Real-time PCR & $\begin{array}{l}\text { Very low prevalence }(0.2 \%) \text { of } \\
\text { macrolide resistance in the } \\
1996-2017 \text { period }\end{array}$ \\
\hline 19 & Uldum et al. [39] & 2012 & Euro Surveillance & Denmark & $\begin{array}{c}\text { Data from MP } \\
\text { national surveillance } \\
\text { system }\end{array}$ & $\begin{array}{l}\text { Children and adults } \\
\qquad(\mathrm{n}=140)\end{array}$ & Real-time PCR & $\begin{array}{l}\text { Low rate of MR-MP infections } \\
(1-3 \%) \text { during the three waves in } \\
\text { the 2010-2011 epidemic }\end{array}$ \\
\hline 20 & Meyer Sauteur et al. [40] & 2014 & $\begin{array}{l}\text { Swiss Medical } \\
\text { Weekly }\end{array}$ & Switzerland & $\begin{array}{l}\text { Prospective study in } \\
\text { out- and inpatients }\end{array}$ & $\begin{array}{l}\text { Children } \\
(\mathrm{n}=50)\end{array}$ & Real-time PCR & $\begin{array}{l}\text { Low level of macrolide resistance } \\
\text { (1/50) during a 3 year period } \\
\text { (2011-2013) }\end{array}$ \\
\hline 21 & Kurkela et al. [41] & 2019 & $\begin{array}{c}\text { European Journal of } \\
\text { Clinical } \\
\text { Microbiology \& } \\
\text { Infectious Disease }\end{array}$ & Finland & $\begin{array}{c}\text { Outbreak } \\
\text { investigation }\end{array}$ & $\begin{array}{l}\text { Children and adults } \\
\quad(\mathrm{n}=535)\end{array}$ & $\begin{array}{l}\text { Real-time PCR, } \\
\text { serology }\end{array}$ & $\begin{array}{l}\text { No MR-MP infections identified } \\
\text { in the } 2017 \text { outbreak in } \\
\text { Kimenlaakso }\end{array}$ \\
\hline 22 & Spuesens et al. [42] & 2012 & $\begin{array}{l}\text { Journal of Clinical } \\
\text { Microbiology }\end{array}$ & The Netherlands & Retrospective study & $\begin{array}{l}\text { Children and adults } \\
\qquad(\mathrm{n}=96)\end{array}$ & Nested-PCR & $\begin{array}{l}\text { MR-MP genotypes not found in } \\
\text { 114 MP positive samples collected } \\
\text { during the 1997-2008 period }\end{array}$ \\
\hline
\end{tabular}

In Italy, the first identification of MR-MP infection in children dates back to 2010 [16], while in adults it was first described during a familial outbreak in 2015 [22]. The prevalence of MR-MP in children during the 2010 epidemic in Italy was estimated to be $26 \%$ [16], whereas a study in 2019 reported a prevalence of $1.3 \%$ among adults with CAP [29]. In 2013, Cardinale et al. demonstrated that the presence of an MR-MP infection in children does not change the presentation of CAP compared with that of macrolide-susceptible MP infection [19]. However, children with MR-MP infection showed a longer duration of fever, cough, hospitalization, and antibiotic administration [19].

The reported prevalence of MR-MP in France in the 2007-2010 endemic period was 3.4\% [30]. In 2011, when an increased incidence of MP infection was registered in most European countries, macrolide resistance-associated mutations were found in samples collected in Bordeaux and Caen, raising the prevalence to $8.3 \%$ in both children and adults [31].

In Spain, MR-MP infection was first identified in 2012 in a 23-year-old Chinese female who returned from China 13 days before CAP onset [32]. After the diagnosis of MP infection, the patient was first treated with macrolides until her clinical condition worsened. Due to the high-rate of macrolide resistance in China, antibiotic treatment was changed to doxycycline, which resulted in a rapid improvement in clinical status. Moreover, in Spain, 
a retrospective analysis of MP infections in children and adults during 2013-2017 revealed that the prevalence of MR-MP strains was $8 \%$ [33].

In the UK, a single-center laboratory-based analysis in Scotland reported MR-MP detection rates of 19\% during the epidemic of 2010-2011 [34]. In England and Wales, the rate of macrolide resistance was $9.3 \%$ in the 2014-2015 period [35].

In Slovenia, the occurrence of MR-MP infections seems sporadic. During a period covering two nationwide epidemics (2010-2011 and 2013-2014), circulation of MR-MP remained low. In particular, a retrospective study of both adults and children during 2006-2014 reported MR-MP infections in 1\% of cases [36], and macrolide resistance was detected in $0.8 \%$ of MP isolates during 2006-2016 [37].

A very low prevalence of MR-MP was reported in Sweden. During the 1996-2017 period, only $0.2 \%$ of identified MP strains showed macrolide resistance [23]. However, a case of MR-MP infection after macrolide treatment was identified [38].

In Denmark, despite high macrolide use during the epidemic of 2010-2011, the reported level of macrolide resistance was 1-3\% [39]. In addition, during a 3-year period in Switzerland (2011-2013), only 1/50 samples revealed high-level macrolide resistance [40].

In the Netherlands and Finland, no MR-MP strains were identified during the 1997-2008 or 2017-2018 epidemics, respectively [41,42].

The MR-MP prevalence rates reported in the European countries are shown in Figure 2.

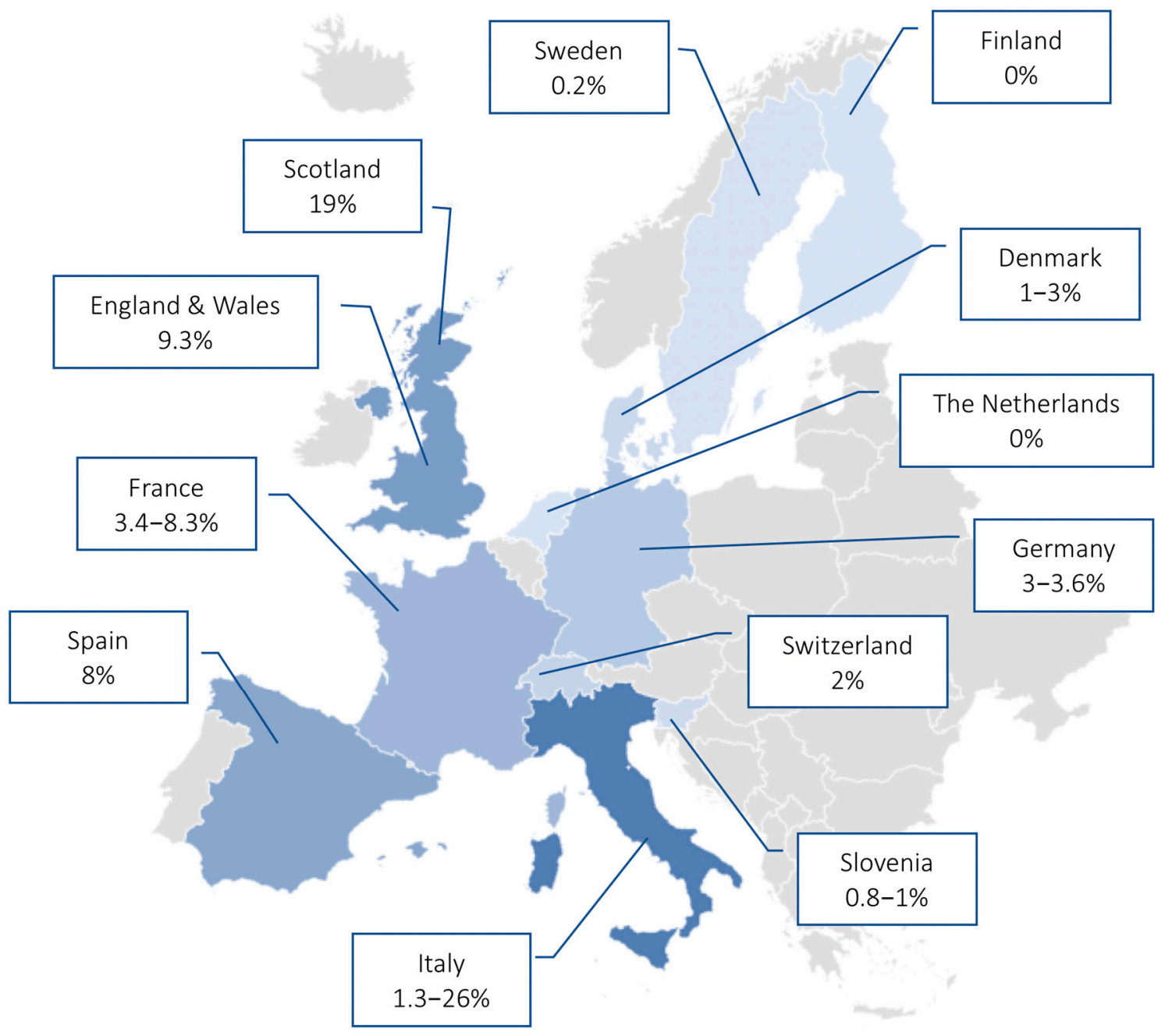

Figure 2. MR-MP prevalence rates reported in the European countries (years 1996-2019). 


\section{Discussion}

This review provides an overview of the spread of MR-MP infection in Europe from 2010. The emergence of MR-MP strains is a public health concern since it represents a worrisome aspect of the global antimicrobial resistance threat. MR-MP strains have emerged since 2000, with rates of macrolide resistance increasing rapidly worldwide [43]. Resistance rates of $80-90 \%$ have been reported in Asia, particularly in China and Japan [43-45]. In recent years, however, there has been marked reduction in the incidence of MR-MP in Japan [46]. This reduction was registered after the 2011-2012 outbreak [47]; indeed, MR-MP rates dropped to $11.3 \%$ during the 2018-2019 period [48]. By contrast, high levels of MR-MP were maintained in China during the 2013-2018 period [49,50]. Compared with Asia, the spread of MR-MP in Europe is quite low. Most European countries lack national surveillance systems, resulting in an underestimation of the spread of MR-MP. This could represent a concern since no rapid alert system is available to identify an increase in MR-MP infections. The surveillance of MP across the European Union and European Economic Area countries is highly variable in terms of data collection and laboratory detection methods, thus making any comparison challenging [51]. The macrolide-resistant rates reported in Europe suggest that MR-MP strains lack a competitive advantage in a population moderately exposed to macrolides [27,52]. The highest prevalence was reported in Italy and Scotland during the 2010-2011 epidemic [16,34], while in the Netherlands and Finland, no MR-MP infections have been reported yet [41,42]. However, the sample sizes of the studies considered in this report were very different, so the prevalence rates should be carefully compared.

The emergence of resistant strains of MP could be induced directly by macrolide use, even after a few days of therapy and particularly when a patient is exposed at suboptimal drug concentrations, as reported for other antibiotics [16,53]. However, it should be considered that a respiratory infection could be caused by a mixed population of susceptible and resistant strains, and that administration of a macrolide as therapy could drive selection of resistant species $[22,54,55]$. MP resistant rates could be influenced by the patient's backgrounds and the epidemiologic situation in each country. For example, the reduction in MR-MP spread reported in recent years in Japan has been associated with the use of tosufloxacine rather than macrolides for the treatment of MP infections [13]. Moreover, the spread of the MP $p 1$ type may also explain this recovery of sensitivity to macrolides in Japan [13].

The usefulness of antibiotic treatment for MP infections is not clear since the majority of infections are self-limiting [56]. Macrolides appear to shorten the duration of symptoms; however, it is not clear whether this effect is due to their antimicrobial or anti-inflammatory properties [19]. In fact, the clinical relevance of MR-MP infections seems to be limited to prolonging symptoms rather than to increasing rates of complications [19], although one study reported that the incidence of extrapulmonary complications was higher in children presenting with MR-MP infection [57]. Replacing clarithromycin with levofloxacin, as reported in the study by Cardinale et al., led to prompt resolution of symptoms [19]. A longer duration of symptoms and hospitalization due to MR-MP infections should be considered as an alarm bell that triggers increased clinical vigilance. It should be considered that differences in MR-MP prevalence between out- and inpatients could be linked to higher rates of hospitalization in more severe cases, and in cases with a history of unsuccessful antibiotic treatment [27].

There is limited evidence regarding whether corticosteroids provide additional benefit for the treatment of MP infections [58]. The rationale underlying the addition of corticosteroids to antibiotics is that in cases with severe low respiratory tract infections caused by $\mathrm{MP}$, the inflammation seems to be triggered by an excessive immune response rather than by the pathogen itself [59].

Atypical pneumoniae syndrome with fever, cough, and shortness of breath caused by MP could be difficult to differentiate from SARS-CoV-2 infection based on clinical presentation alone [60]. Those managing COVID-19 patients should bear in mind the possibility 
of the presence of other respiratory pathogens that cause co-infections. Co-infections of MP plus SARS-CoV-2 have been reported in the literature [61] and are associated with more severe disease characteristics [62]. Therefore, a SARS-CoV-2 diagnostic test should be undertaken, along with tests for other respiratory pathogens, to ensure better management of the patients.

\section{Conclusions}

Monitoring the macrolide resistance of MP infection in Europe should be continued. Further studies based on whole-genome sequencing of MR-MP strains are needed to better understand the mechanisms underlying resistance and to investigate outbreaks. In addition, it is important to maintain low rates of infection. Moreover, a coordinated and structured surveillance program across Europe is required, both as a public health measure and to contain the spread of antimicrobial resistance.

Author Contributions: Conceptualization, D.L. and M.C.; methodology, D.L.; software, F.C., C.M. and S.C.; validation, A.L.D.R. and A.S.; data curation, F.C. and M.A.; writing-original draft preparation, D.L.; writing-review and editing, M.C. All authors have read and agreed to the published version of the manuscript.

Funding: This research received no external funding.

Institutional Review Board Statement: Not applicable.

Informed Consent Statement: Not applicable.

Data Availability Statement: Not applicable.

Conflicts of Interest: The authors declare no conflict of interest.

\section{References}

1. Jain, S.; Williams, D.J.; Arnold, S.R.; Ampofo, K.; Bramley, A.M.; Reed, C.; Stockmann, C.; Anderson, E.J.; Grijalva, C.G.; Self, W.H.; et al. Community-acquired pneumonia requiring hospitalization among U.S. children. N. Engl. J. Med. 2015, 372, 835-845. [CrossRef] [PubMed]

2. Shin, E.J.; Kim, Y.; Jeong, J.Y.; Jung, Y.M.; Lee, M.H.; Chung, E.H. The changes of prevalence and etiology of pediatric pneumonia from National Emergency Department Information System in Korea, between 2007 and 2014. Korean J. Pediatr. 2018, 61, 291-300. [CrossRef]

3. Waites, K.B.; Talkington, D.F. Mycoplasma pneumoniae and its role as a human pathogen. Clin. Microbiol. Rev. 2004, 17, 697-728. [CrossRef] [PubMed]

4. Principi, N.; Esposito, S. Macrolide-resistant Mycoplasma pneumoniae: Its role in respiratory infection. J. Antimicrob. Chemother. 2013, 68, 506-511. [CrossRef]

5. Narita, M. Pathogenesis of extrapulmonary manifestations of Mycoplasma pneumoniae infection with special reference to pneumonia. J. Infect. Chemother. 2010, 16, 162-169. [CrossRef] [PubMed]

6. de Groot, R.C.A.; Meyer Sauteur, P.M.; Unger, W.W.J.; van Rossum, A.M.C. Things that could be Mycoplasma pneumoniae. J. Infect. 2017, 74, S95-S100. [CrossRef]

7. Dumke, R.; Catrein, I.; Herrmann, R.; Jacobs, E. Preference, adaptation and survival of Mycoplasma pneumoniae subtypes in an animal model. Int. J. Med. Microbiol. 2004, 294, 149-155. [CrossRef] [PubMed]

8. Atkinson, T.P.; Balish, M.F.; Waites, K.B. Epidemiology, clinical manifestations, pathogenesis and laboratory detection of Mycoplasma pneumoniae infections. FEMS Microbiol. Rev. 2008, 32, 956-973. [CrossRef]

9. Rasmussen, J.N.; Voldstedlund, M.; Andersen, R.L.; Ellermann-Eriksen, S.; Jensen, T.G.; Johansen, H.K.; Kolmos, B.; Mølvadgaard, M.; Nielsen, S.S.; Olsen, E.; et al. Increased incidence of Mycoplasma pneumoniae infections detected by laboratory-based surveillance in Denmark in 2010. Eur. Surveill. 2010, 15, 19708, Erratum in Euro Surveill. 2010, 25, 15. [CrossRef]

10. Kenri, T.; Okazaki, N.; Yamazaki, T.; Narita, M.; Izumikawa, K.; Matsuoka, M.; Suzuki, S.; Horino, A.; Sasaki, T. Genotyping analysis of Mycoplasma pneumoniae clinical strains in Japan between 1995 and 2005: Type shift phenomenon of M. pneumoniae clinical strains. J. Med. Microbiol. 2008, 57, 469-475. [CrossRef]

11. von Baum, H.; Welte, T.; Marre, R.; Suttorp, N.; LuÃàck, C.; Ewig, S. Mycoplasma pneumoniae pneumonia revisited within the German Competence Network for Community-acquired pneu- monia (C.A.P.N.E.T.Z). BMC Infect. Dis. 2009, 9, 62. [CrossRef] [PubMed]

12. Principi, N.; Esposito, S. Emerging role of Mycoplasma pneumoniae and Chlamydia pneumoniae in paediatric respiratory-tract infections. Lancet Infect. Dis. 2001, 1, 334-344. [CrossRef] 
13. Oishi, T.; Takahashi, K.; Wakabayashi, S.; Nakamura, Y.; Ono, S.; Kono, M.; Kato, A.; Saito, A.; Kondo, E.; Tanaka, Y.; et al. Comparing Antimicrobial Susceptibilities among Mycoplasma pneumoniae Isolates from Pediatric Patients in Japan between Two Recent Epidemic Periods. Antimicrob. Agents Chemother. 2019, 63, e02517-e02518. [CrossRef]

14. Okazaki, N.; Narita, M.; Yamada, S.; Izumikawa, K.; Umetsu, M.; Kenri, T.; Sasaki, Y.; Arakawa, Y.; Sasaki, T. Characteristics of macrolide-resistant Mycoplasma pneumoniae strains isolated from patients and induced with erythromycin in vitro. Microbiol. Immunol. 2001, 45, 617-620. [CrossRef] [PubMed]

15. Morozumi, M.; Takahashi, T.; Ubukata, K. Macrolide-resistant Mycoplasma pneumoniae: Characteristics of isolates and clinical aspects of community-acquired pneumonia. J. Infect. Chemother. 2010, 16, 78-86. [CrossRef]

16. Chironna, M.; Sallustio, A.; Esposito, S.; Perulli, M.; Chinellato, I.; Di Bari, C.; Quarto, M.; Cardinale, F. Emergence of macrolideresistant strains during an outbreak of Mycoplasma pneumoniae infections in children. J. Antimicrob. Chemother. 2011, 66, 734-737. [CrossRef]

17. Miyashita, N.; Maruyama, T.; Kobayashi, T.; Kobayashi, H.; Taguchi, O.; Kawai, Y.; Yamaguchi, T.; Ouchi, K.; Oka, M. Communityacquired macrolide-resistant Mycoplasma pneumoniae pneumonia in patients more than 18 years of age. J. Infect. Chemother. 2011, 17, 114-118. [CrossRef]

18. Li, S.L.; Sun, H.M.; Zhu, B.L.; Liu, F.; Zhao, H.Q. Whole Genome Analysis Reveals New Insights into Macrolide Resistance in Mycoplasma pneumoniae. Biomed Environ. Sci. 2017, 30, 343-350.

19. Cardinale, F.; Chironna, M.; Chinellato, I.; Principi, N.; Esposito, S. Clinical relevance of Mycoplasma pneumoniae macrolide resistance in children. J. Clin. Microbiol. 2013, 51, 723-724. [CrossRef]

20. Pereyre, S.; Goret, J.; Bébéar, C. Mycoplasma pneumoniae: Current Knowledge on Macrolide Resistance and Treatment. Front. Microbiol. 2016, 22, 974. [CrossRef]

21. Dorigo-Zetsma, J.W.; de Wit, M.; Szabo, J.N.; Schneeberger, P.M. Epidemie van luchtweginfecties door Mycoplasma pneumoniae in een instelling voor verstandelijk gehandicapten onderzocht met polymerasekettingreactie op keeluitstrijk [Epidemic of respiratory tract infections by Mycoplasma pneumoniae in an institute for mentally disabled, investigated with polymerase chain reaction of a throat swab specimen]. Ned. Tijdschr. Geneeskd. 1999, 143, 1261-1265.

22. Chironna, M.; Loconsole, D.; De Robertis, A.L.; Morea, A.; Scalini, E.; Quarto, M.; Tafuri, S.; Germinario, C.; Manzionna, M. Clonal Spread of a Unique Strain of Macrolide-Resistant Mycoplasma Pneumoniae Within a Single Family in Italy. Medicine 2016, 95, e3160. [CrossRef]

23. Gullsby, K.; Olsen, B.; Bondeson, K. Molecular Typing of Mycoplasma pneumoniae Strains in Sweden from 1996 to 2017 and the Emergence of a New P1 Cytadhesin Gene, Variant 2e. J. Clin. Microbiol. 2019, 57, e00049-19. [CrossRef] [PubMed]

24. Xu, C.; Deng, H.; Zhang, J.; Zhu, Y.; Rong, Q.; Quan, Y.; Tang, H.; Zhao, D. Mutations in domain V of Mycoplasma pneumoniae $23 S$ rR.N.A and clinical characteristics of pediatric M. pneumoniae pneumonia in Nanjing, China. J. Int. Med. Res. 2021, 49. [CrossRef] [PubMed]

25. Dumke, R.; Lück, C.; Jacobs, E. Low rate of macrolide resistance in Mycoplasma pneumoniae strains in Germany between 2009 and 2012. Antimicrob. Agents Chemother. 2013, 57, 3460. [CrossRef] [PubMed]

26. Dumke, R.; Schnee, C.; Pletz, M.W.; Rupp, J.; Jacobs, E.; Sachse, K.; Rohde, G.; Capnetz Study Group. Mycoplasma pneumoniae and Chlamydia spp. infection in community-acquired pneumonia, Germany, 2011-2012. Emerg. Infect. Dis. 2015, 21, 426-434. [CrossRef]

27. Dumke, R.; Ziegler, T. Long-Term Low Rate of Macrolide-Resistant Mycoplasma pneumoniae Strains in Germany. Antimicrob. Agents Chemother. 2019, 63, e00455-19. [CrossRef]

28. Dumke, R.; Stolz, S.; Jacobs, E.; Juretzek, T. Molecular characterization of macrolide resistance of a Mycoplasma pneumoniae strain that developed during therapy of a patient with pneumonia. Int. J. Infect. Dis. 2014, 29, 197-199. [CrossRef]

29. Loconsole, D.; De Robertis, A.L.; Mallamaci, R.; Sallustio, A.; Morea, A.; Prato, R.; Quarto, M.; Martinelli, D.; Chironna, M. First Description of Macrolide-Resistant Mycoplasma pneumoniae in Adults with Community-Acquired Pneumonia in Italy. Biomed. Res. Int. 2019, 2019, 7168949. [CrossRef]

30. Pereyre, S.; Charron, A.; Hidalgo-Grass, C.; Touati, A.; Moses, A.E.; Nir-Paz, R.; Bébéar, C. The spread of Mycoplasma pneumoniae is polyclonal in both an endemic setting in France and in an epidemic setting in Israel. PLoS ONE 2012, 7, e38585. [CrossRef]

31. Pereyre, S.; Touati, A.; Petitjean-Lecherbonnier, J.; Charron, A.; Vabret, A.; Bébéar, C. The increased incidence of Mycoplasma pneumoniae in France in 2011 was polyclonal, mainly involving M. pneumoniae type 1 strains. Clin. Microbiol. Infect. 2013, 19, E212-E217. [CrossRef] [PubMed]

32. Caballero Jde, D.; del Campo, R.; del Carmen Mafé, M.; Gálvez, M.; Rodríguez-Domínguez, M.; Cantón, R.; Meseguer, M.A.; Hermida, J.M. First report of macrolide resistance in a Mycoplasma pneumoniae isolate causing community-acquired pneumonia in Spain. Antimicrob. Agents Chemother. 2014, 58, 1265-1266. [CrossRef]

33. Rivaya, B.; Jordana-Lluch, E.; Fernández-Rivas, G.; Molinos, S.; Campos, R.; Méndez-Hernández, M.; Matas, L. Macrolide resistance and molecular typing of Mycoplasma pneumoniae infections during a 4 year period in Spain. J. Antimicrob. Chemother. 2020, 75, 2752-2759. [CrossRef] [PubMed]

34. Ferguson, G.D.; Gadsby, N.J.; Henderson, S.S.; Hardie, A.; Kalima, P.; Morris, A.C.; Hill, A.T.; Cunningham, S.; Templeton, K.E. Clinical outcomes and macrolide resistance in Mycoplasma pneumoniae infection in Scotland, U.K. J. Med. Microbiol. 2013, 62, 1876-1882. [CrossRef] [PubMed] 
35. Brown, R.J.; Macfarlane-Smith, L.; Phillips, S.; Chalker, V.J. Detection of macrolide resistant Mycoplasma pneumoniae in England, September 2014 to September 2015. Eur. Surveill. 2015, 20, 30078. [CrossRef]

36. Kogoj, R.; Mrvic, T.; Praprotnik, M.; Kese, D. Prevalence, genotyping and macrolide resistance of Mycoplasma pneumoniae among isolates of patients with respiratory tract infections, Central Slovenia, 2006 to 2014. Eur. Surveill. 2015, 20. [CrossRef] [PubMed]

37. Kogoj, R.; Praprotnik, M.; Mrvifç, T.; Korva, M.; Keše, D. Genetic diversity and macrolide resistance of Mycoplasma pneumoniae isolates from two consecutive epidemics in Slovenia. Eur. J. Clin. Microbiol. Infect. Dis. 2018, 37, 99-107. [CrossRef]

38. Nilsson, A.C.; Jensen, J.S.; Björkman, P.; Persson, K. Development of macrolide resistance in Mycoplasma pneumoniae-infected Swedish patients treated with macrolides. Scand. J. Infect. Dis. 2014, 46, 315-319. [CrossRef] [PubMed]

39. Uldum, S.A.; Bangsborg, J.M.; Gahrn-Hansen, B.; Ljung, R.; Mølvadgaard, M.; Petersen, R.F.; Svarrer, C.W. Epidemic of Mycoplasma pneumoniae infection in Denmark, 2010 and 2011. Eur. Surveill. 2012, 17, 20073. [CrossRef]

40. Meyer Sauteur, P.M.; Bleisch, B.; Voit, A.; Maurer, F.P.; Relly, C.; Berger, C.; Nadal, D.; Bloemberg, G.V. Survey of macrolideresistant Mycoplasma pneumoniae in children with community-acquired pneumonia in Switzerland. Swiss Med. Wkly. 2014, 144, w14041. [CrossRef] [PubMed]

41. Kurkela, S.; Puolakkainen, M.; Hokynar, K.; Nieminen, T.; Saxen, H.; Mannonen, L.; Pietikäine, R. Mycoplasma pneumoniae outbreak, Southeastern Finland, 2017-2018: Molecular epidemiology and laboratory diagnostic lessons. Eur. J. Clin. Microbiol. Infect. Dis. 2019, 38, 1867-1871. [CrossRef]

42. Spuesens, E.B.; Meijer, A.; Bierschenk, D.; Hoogenboezem, T.; Donker, G.A.; Hartwig, N.G.; Koopmans, M.P.; Vink, C.; van Rossum, A.M. Macrolide resistance determination and molecular typing of Mycoplasma pneumoniae in respiratory specimens collected between 1997 and 2008 in The Netherlands. J. Clin. Microbiol. 2012, 50, 1999-2004. [CrossRef]

43. Wang, Y.; Xu, B.; Wu, X.; Yin, Q.; Wang, Y.; Li, J.; Jiao, W.; Quan, S.; Sun, L.; Wang, Y.; et al. Increased Macrolide Resistance Rate of M3562 Mycoplasma pneumoniae Correlated with Macrolide Usage and Genotype Shifting. Front. Cell. Infect. Microbiol. 2021, 11, 675466. [CrossRef] [PubMed]

44. Sun, H.; Xue, G.; Yan, C.; Li, S.; Zhao, H.; Feng, Y.; Wang, L. Changes in Molecular Characteristics of Mycoplasma pneumoniae in Clinical Specimens from Children in Beijing between 2003 and 2015. PLoS ONE 2017, 12, e0170253. [CrossRef] [PubMed]

45. Yan, C.; Xue, G.; Zhao, H.; Feng, Y.; Li, S.; Cui, J.; Ni, S.; Sun, H. Molecular and clinical characteristics of severe Mycoplasma pneumoniae pneumonia in children. Pediatr. Pulmonol. 2019, 54, 1012-1021. [CrossRef]

46. Nakamura, Y.; Oishi, T.; Kaneko, K.; Kenri, T.; Tanaka, T.; Wakabayashi, S.; Kono, M.; Ono, S.; Kato, A.; Kondo, E.; et al. Recent acute reduction in macrolide-resistant Mycoplasma pneumoniae infections among Japanese children. J. Infect. Chemother. 2021, 27, 271-276. [CrossRef] [PubMed]

47. Okada, T.; Morozumi, M.; Tajima, T.; Hasegawa, M.; Sakata, H.; Ohnari, S.; Chiba, N.; Iwata, S.; Ubukata, K. Rapid effectiveness of minocycline or doxycycline against macrolide-resistant Mycoplasma pneumoniae infection in a 2011 outbreak among Japanese children. Clin. Infect. Dis. 2012, 55, 1642-1649. [CrossRef]

48. Morozumi, M.; Tajima, T.; Sakuma, M.; Shouji, M.; Meguro, H.; Saito, K.; Iwata, S.; Ubukata, K. Sequence Type Changes Associated with Decreasing Macrolide-Resistant Mycoplasma pneumoniae, Japan. Emerg. Infect. Dis. 2020, 26, 2210-2213. [CrossRef]

49. Xue, G.; Li, M.; Wang, N.; Zhao, J.; Wang, B.; Ren, Z.; Yan, C.; Wu, C.; Liu, Y.; Sun, H.; et al. Comparison of the molecular characteristics of Mycoplasma pneumoniae from children across different regions of China. PLoS ONE 2018, 13, e0198557. [CrossRef]

50. Zhao, F.; Li, J.; Liu, J.; Guan, X.; Gong, J.; Liu, L.; He, L.; Meng, F.; Zhang, J. Antimicrobial susceptibility and molecular characteristics of Mycoplasma pneumoniae isolates across different regions of China. Antimicrob. Resist. Infect. Control. 2019, 8, 143. [CrossRef]

51. Lenglet, A.; Herrador, Z.; Magiorakos, A.P.; Leitmeyer, K.; Coulombier, D. European Working Group on Mycoplasma pneumoniae surveillance. Surveillance status and recent data for Mycoplasma pneumoniae infections in the European Union and European Economic Area, January 2012. Eur. Surveill. 2012, 17, 20075. [CrossRef]

52. Adriaenssens, N.; Coenen, S.; Versporten, A.; Muller, A.; Minalu, G.; Faes, C.; Vankerckhoven, V.; Aerts, M.; Hens, N.; Molenberghs, G.; et al. European Surveillance of Antimicrobial Consumption (ESA: Outpatient macrolide, lincosamide and streptogramin (MLS) use in Europe (1997-2009). J. Antimicrob. Chemother. 2011, 66, vi37-vi45. [CrossRef] [PubMed]

53. Pereyre, S.; Guyot, C.; Renaudin, H.; Charron, A.; Bébéar, C.; Bébéar, C.M. In vitro selection and characterization of resistance to macrolides and related antibiotics in Mycoplasma pneumoniae. Antimicrob. Agents Chemother. 2004, 48, 460-465. [CrossRef] [PubMed]

54. Averbuch, D.; Hidalgo-Grass, C.; Moses, A.E.; Engelhard, D.; Nir-Paz, R. Macrolide resistance in Mycoplasma pneumoniae, Israel, 2010. Emerg. Infect. Dis. 2011, 17, 1079-1082. [CrossRef]

55. Li, J.; Liu, L.; He, L.; Meng, F.; Zhang, J.; Zhao, F. First report of macrolide-resistant and -susceptible Mycoplasma pneumoniae clinical strains isolated from a single case. J. Glob. Antimicrob. Resist. 2021, 24, 228-232. [CrossRef]

56. Yu, J.L.; Song, Q.F.; Xie, Z.W.; Jiang, W.H.; Chen, J.H.; Fan, H.F.; Xie, Y.P.; Lu, G. iTRAQ-based Quantitative Proteomics Study in Patients with Refractory Mycoplasma pneumoniae Pneumonia. Jpn. J. Infect. Dis. 2017, 70, 571-578. [CrossRef]

57. Zhou, Y.; Zhang, Y.; Sheng, Y.; Zhang, L.; Shen, Z.; Chen, Z. More complications occur in macrolide-resistant than in macrolidesensitive Mycoplasma pneumoniae pneumonia. Antimicrob. Agents Chemother. 2014, 58, 1034-1038. [CrossRef] 
58. Spuesens, E.B.; Meyer Sauteur, P.M.; Vink, C.; van Rossum, A.M. Mycoplasma pneumoniae infections-does treatment help? J. Infect. 2014, 69, S42-S46. [CrossRef]

59. Luo, Z.; Luo, J.; Liu, E.; Xu, X.; Liu, Y.; Zeng, F.; Li, S.; Fu, Z. Effects of prednisolone on refractory mycoplasma pneumoniae pneu-monia in children. Pediatr. Pulmonol. 2014, 49, 377. [CrossRef]

60. World Health Organization. Clinical Management of COVID-19, Interim Guidance. 27 May 2020. Available online: https: / / www.who.int/publications/i/item/clinical-management-of-covid-19 (accessed on 8 July 2021).

61. Oliva, A.; Siccardi, G.; Migliarini, A.; Cancelli, F.; Carnevalini, M.; D'Andria, M.; Attilia, I.; Danese, V.C.; Cecchetti, V.; Romiti, R.; et al. Co-infection of SARS.-CoV-2 with Chlamydia or Mycoplasma pneumoniae: A case series and review of the literature. Infection 2020, 48, 871-877. [CrossRef] [PubMed]

62. De Francesco, M.A.; Poiesi, C.; Gargiulo, F.; Bonfanti, C.; Pollara, P.; Fiorentini, S.; Caccuri, F.; Carta, V.; Mangeri, L.; Pellizzeri, S.; et al. Co-infection of chlamydia pneumoniae and mycoplasma pneumoniae with SARS-CoV-2 is associated with more severe features. J. Infect. 2021, 82, e4-e7. [CrossRef] [PubMed] 